\title{
Developing multilingual practices in early childhood education through a professional development in Luxembourg
}

\author{
Claudine Kirsch, Gabrijela Aleksić, Simone Mortini, Katja Andersen \\ (University of Luxembourg, Faculty of Humanities, Education and Social Sciences)
}

\begin{abstract}
This paper investigates seven early education practitioners' attitudes towards multilingual activities and translanguaging as well as their actual practices in Luxembourg. They took part in a professional development comprising a course, coaching, and regular meetings to deepen their understanding of multilingualism and language learning, and enable them to implement activities in multiple languages.

The findings, drawn from questionnaires, observations, and interviews, show that all practitioners opened up towards multilingual activities and translanguaging, increased activities in such languages, and translanguaged frequently. The practitioners analyzed their beliefs and practices, connected theory and practice, constructed new knowledge, developed positive attitudes and changed their practice. This study is the first one to investigate the attitudes and practices of professionals in formal and non-formal education settings as well as the effect of professional development in Luxembourg. It also addresses the research gap regarding professional development on multilingualism in early childhood.
\end{abstract}

Keywords: professional development; early childhood; multilingualism; translanguaging; attitudes

\section{Developing multilingual practices in early childhood education through professional development in Luxembourg}

\section{Introduction}

Programs in multilingual education in early childhood can be rooted in multilingual pedagogies developed in the U.S. by García and her colleagues (García and Flores, 2011) as a means of redressing educational inequalities and enhancing social participation. In Europe, they can also be a response to policies on early language learning which aim at the development of language and cultural awareness, openness and social skills (Council of the European Union, 2011). These programmes are influenced by research findings on bilingualism in education and neuroscience suggesting that all speakers draw flexibly on their languages (e.g. García, 2017), demonstrating cognitive and linguistic effects of bilingualism (e.g. Bialystok, 2017) and highlighting the benefits of early language learning. A multilingual education is certainly essential in a world shaped by migration and globalisation. Programs have been implemented in several European countries but the focus 
often remains on the majority language with little space given to home languages (Kratzmann et al., 2017).

In Luxembourg, a small country in the centre of Europe, new language-in-education policies were implemented in 2017. Bordering France, Belgium and Germany, Luxembourg is trilingual by law. Apart from Luxembourgish, French and German, the three official languages, many more are spoken on account of the high number of immigrant residents. Currently, 47,5\% of the residents do not have Luxembourgish citizenship (STATEC, 2019). While multilingualism is the reality in the Luxembourgish society, the percentage of fouryear-olds who do not speak Luxembourgish was 63,7\% in the academic year 2016/17 (MENJE, 2019). To implement a multilingual approach that capitalizes on children's resources, practitioners need to open-up to flexible language use. Professional development has been hailed as the key method to help practitioners develop knowledge, skills, and practices (Peleman et al., 2017) and may, therefore, also contribute to the development of multilingual approaches.

This paper draws its data from the project 'Developing Multilingual Pedagogies in Early Childhood' (MuLiPEC) which investigated multilingual practices in formal and nonformal early childhood education in Luxembourg. It presents the changes in seven practitioners' attitudes towards multilingual activities and translanguaging, the number of activities in non-institutional languages, and the use of translanguaging through professional development. Drawing on qualitative and quantitative methods, the findings show that the professional development contributed to changes in attitudes and practices. The article concludes with a conceptualization of their professional learning which contributes to our understanding of the ways in which collaborative and inquiry-based professional development in multilingual education in early childhood can influence change.

\section{Transforming practices through professional development}

The following sections present relevant literature both on translanguaging, a pillar of multilingual pedagogies, and professional development.

\subsection{Translanguaging in education}

The term translanguaging was first introduced by Williams (1994) in the Welsh context where the educational aim was to develop expertise in both English and Welsh 
simultaneously and to a high standard (Lewis, Jones, and Baker, 2012). García and her colleagues in the US as well as Li Wei in the UK developed translanguaging into a theory that holds that all language users have a unique linguistic repertoire from which they select and combine resources to suit the needs of the communicative situation at hand (Otheguy, García \& Reid, 2015; Li Wei, 2018). Languages are not seen as separate but integrated and dynamic while constantly interacting. Translanguaging privileges the perspectives of the speakers and draws attention to their agentive behavior and practices. At the same time, it acknowledges the effects of named languages and language ideologies on language practices (Otheguy et al., 2015). Translanguaging as a theory and a pedagogy challenges hegemonic ideologies and monolingual educational practices.

While translanguaging denotes fluid and dynamic linguistic and non-linguistic practices in sociolinguistics terms, translanguaging as a pedagogy refers to an instructional and assessment framework. Teachers can use this framework strategically to support student engagement and comprehension, develop linguistic practices for academic purposes, create spaces for the students' multilingualism, and support the students' socio-emotional development and multilingual identities (García, Johnson, \& Seltzer, 2017). García et al. (2017) identified stance, design and shifts as three important components of a translanguaging pedagogy. Stance refers to the teachers' commitment to draw on the students' full linguistic repertoire. Design regards the deployment of language, activities and curricula that enable students to connect home languages and cultures to school and establish more durable home-school relations. Shifts refer to the unplanned, flexible use of languages and pedagogical strategies to accommodate students' needs and meaning making.

Translanguaging has important educational advantages. Referring to Baker, García, and Li Wei $(2014,64)$ list four of them: it may promote a deeper and fuller understanding of the subject matter; further the development of the weaker language; facilitate home-school links and cooperation, and contribute to the integration of early language learners.

Very few researchers have examined translanguaging with young children. Language learners translanguage naturally and draw on their entire semiotic repertoire by using mime, gestures, posture, and intonation to communicate and make meaning. García et al. (2011) points out that children translanguage to mediate understanding, co-construct meaning and show knowledge. Some studies confirmed these frequently used functions (Alamillo, Yun, \& Bennett, 2017, Chapman de Sousa, 2017, Kirsch, 2017). Other researchers have demonstrated the positive effects of translanguaging in early education (Young and Mary 2016). Gort and Sembiante (2015) observed teachers use Spanish and English dynamically 
and encouraging children to translanguage in a preschool. The teachers legitimized the children's use of different language varieties and experimentation with language forms, not only with the aim of developing language and literacy but also of allowing children to express their bilingual identities. The authors concluded that translanguaging pedagogies supported educational, affective, linguistic, and sociocultural development. More recently, Velasco and Fialais (2018) observed interactions between a bilingual teacher and children in a bilingual French-German kindergarten in France. The teacher created a translanguaging space where the children analyzed cognates and false cognates in German and French. The authors noticed that the children demonstrated metalinguistic awareness particularly in relation to phonology and print, and were able to reflect on their bilingual practices, skills, and identities.

\subsection{Professional development on language education in Early Childhood}

Professional development (thereafter PD) has been defined as the systematic effort to provide professionals with opportunities to complement, consolidate and develop their professional attitudes, knowledge, and skills (Peeters et al., 2014). It may lead to a deeper understanding of learning theories, changed attitudes, improved skills and greater reflectivity. It may also target a change of practice which can imply that professionals deconstruct and re-conceptualize their role (Peleman et al., 2017). PD can improve the quality in early childhood education and care (ECEC) services (Egert, Fukkink, \& Eckhardt, 2018; Peeters et al., 2014).

Professional development can precipitate change in several ways. According to Bandura's (1986) social learning theory, change can result from observing others, and 'noticing' specific aspects and implementing these in one's own practice (Star and Strickland, 2008). Hamre et al. (2012), for instance, trained teachers to identify interaction strategies in videos, helping the professionals implement social and interactional strategies in their own interactions with children. Other researchers developed the idea of a stage model whereby PD influences firstly attitudes, knowledge and skills which, secondly, affect practices which, in turn, influence child development (Fukkink and Lont, 2007). Several meta-studies showed that PD can have a long-term impact on practitioners' outcomes and practices (Peleman et al., 2017; Peeters et al., 2014). Positive effects were found with respect to the practitioners' pedagogical awareness, professional understanding, quality of teaching and practice of reflection (Egert et al., 2018; Peleman et al., 2017). However, the 
influence on child development was relatively small (Egert et al., 2018). In general, the findings of these meta-studies are inconclusive on account of the range of designs, settings, and contexts.

While these meta-studies show some influence of $\mathrm{PD}$, they also point to a research gap in relation to language learning and multilingualism. The few existing studies indicate a positive influence on language practices. For instance, Buschmann and Sachse (2018) found that PD with video-recordings of the practitioners' interactions with children with language delay, helped the practitioners develop language stimulation behavior and create responsive communication situations. Studies on PD participants working with multilingual children indicate positive effects both on practitioners' outcomes (Kirsch \& Aleksić, 2018) and children's language competences (Sachse, Schuler, \& Budde-Spengler, 2016).

Research into the efficiency of different types of PD has produced contradictory findings. Meta-studies show that PD that is integrated in the ECEC center's practice and includes training, reflection, and coaching can be effective if it is long-term, collaborative, performance-based, and inquiry-based (Egert et al., 2018; Peeters et al., 2014; Peleman et al., 2017). Short-term PD can be effective when supported by video-recording. The videos engage professionals in systematic reflection of their planning and teaching which can sustain the effect of the PD (Peeters et al., 2014).

In sum, this literature review has shown that translanguaging as a pedagogy can challenge monolingual ideologies and offer spaces for flexible language use. PD may help practitioners implement this pedagogy. While PD in language education in ECEC can influence teacher outcomes and practices to some extent, there are few studies on PD that either focused on multilingualism or targeted multilingual pedagogies. The present study bridges this gap. Before presenting the findings of our professional development, we will outline provision for early childhood education in Luxembourg.

\section{Early childhood education in Luxembourg}

The Luxembourgish early childhood education system is divided into a formal and a nonformal sector. The non-formal sector comprises day-care centers as well as state-funded and private crèches, which provide education and care for children from birth to twelve years. The formal early childhood education consists of the two-year compulsory preschool for children aged four to six and the éducation précoce, a non-compulsory year for children aged three (Kirsch \& Aleksić, 2018). 
Staffing and the number of children per practitioner are two of the essential differences between these settings. Teachers work in the formal sector whereas caregivers can work in the non-formal sector as well as in preschool when collaborating with a teacher. While there are on average sixteen children in a preschool, the child-caregiver-ratio in the non-formal settings is restricted to one caregiver for eight three-year-old children. Figure 1 visualizes the Luxembourgish ECEC system, indicating the sector, the age of the children and the practitioners. $\mathrm{T}$ stands for teacher and $\mathrm{C}$ for caregiver.

Figure 1. Overview of ECEC in Luxembourg

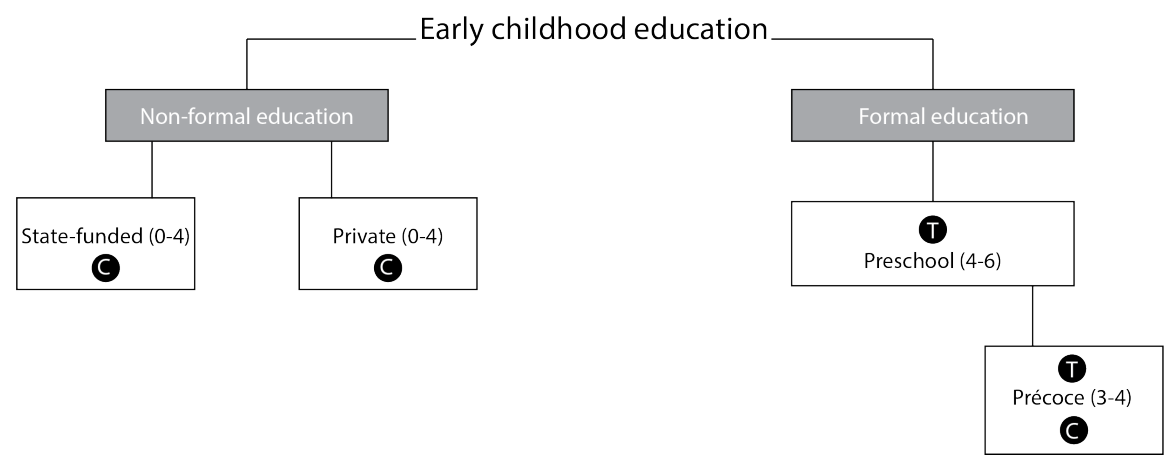

Regarding language policies, early childhood education in the formal setting traditionally focused on the national language Luxembourgish. In spite of the absence of language policy guidelines in the non-formal setting until 2017, and the fact that multilingualism is the reality in everyday practice, practitioners held on to monolingual ideologies and norms, particularly in situations where they promoted language learning (Neumann, 2015). The regulated use of Luxembourgish as the language of integration and social cohesion was legitimated by the society's language diversity and the challenging trilingual education system in primary school (MENFP, 2005). In Year 1, children become literate in German and, since the Primary Education Act of 2017, they also develop oral skills in French. They learn its written form in Year 3. Luxembourgish is the language of instruction of the non-academic subjects (e.g. Arts), and German of the academic ones (e.g. mathematics).

National assessment studies have continuously shown that primary school children with migration background and low socioeconomic status are outperformed by their Luxembourgish-speaking peers (MENJE, 2018a). In the academic year of 2016/17, 63,7\% of the children entering formal early childhood education spoke a home language other than 
Luxembourgish (MENJE, 2019). In response to the ever-increasing language diversity and the growing disparities in school achievements, the government made changes to the Children and Youth Act and the Primary Education Act in 2017. These laws give young children additional time to learn Luxembourgish and French and aim to increase their school achievement. Formal and non-formal early childhood practitioners are now required to develop children's skills in Luxembourgish, familiarize them with French and value their home languages. The objectives of the multilingual education include fostering openmindedness and curiosity as well as language development (MENJE and SNJ, 2018).

Our research project MuLiPEC was in planning at the same time as the new laws on multilingual education were being discussed. The wish to develop an effective multilingual approach on account of the diverse population and the unequal opportunities, was common to the law and our research project. We aimed to develop a resource-oriented pedagogy which capitalized on children's multilingual resources and drew on languages other than the institutional language Luxembourg. The research questions addressed in this paper read as follows:

(1) To what extent did seven professionals change their attitudes towards multilingual activities and translanguaging during the PD?

(2) To what extent and in what ways did they implement activities in languages other than the institutional language?

(3) To what extent did they translanguage?

\section{Methodology}

This paper draws its data from the research project MuLiPEC. We offered a professional development course to familiarize practitioners with multilingual pedagogies. Following an 'integrated model' (Peeters et al., 2014) the PD had three parts: training sessions, network meetings and coaching. In Summer 2016, we organized a 15-hour course on multilingual education attended by 46 teachers and caregivers. Seven of these continued to work with us for an entire academic year. Three worked in formal education - a preschool and an éducation précoce - and four in non-formal education - a crèche and a day-care center. They were given the opportunity to attend 6 network meetings, and were coached by Kirsch from September 2016 to July 2017. 
The aims of the PD were to further the professionals' understanding of multilingualism and language learning, and help them implement activities in institutional languages (e.g. Luxembourgish, French) and the children's other home languages. The topics covered included perspectives on multilingualism, theories of language learning, pedagogical principles, literacy activities around books, songs, and rhymes as well as languagesupporting strategies. A central part of the PD was the discussion of the practitioners' language activities video-recorded by the practitioners or the research team. Our model, based on successful trainings reported in Peeters et al. (2014), was collaborative, inquirybased, performance based and promoted reflection.

\subsection{The participants}

The sample of our study included two teachers and five caregivers, aged between 30 and 39 with working experience of more than ten years. Ms. Vivian (teacher) worked with fouryear-olds in a preschool and Ms. Clara (teacher) and Ms. Jane (caregiver) were in charge of three-year-olds in an éducation précoce. Ms. Sandy and Ms. Anna worked with three-yearolds in a crèche and Mr. Ted and Mr. Ken with a similar age group in day-care center. All professionals spoke Luxembourgish, German, French, and English. In addition, Ms. Sandy and Mr. Ken grew up bilingually and also spoke Portuguese and Spanish respectively. Ms. Clara had learned some Portuguese and Ms. Vivian Spanish. While the language diversity was high in all four settings, the social-economic status (SES) of the children enrolled varied. In the three institutions around the Center of Luxembourg, the SES and the range of languages spoken was high. By contrast, most children in the South spoke Portuguese, French or Italian and came from working-class families. Luxembourgish was the main language used in all settings but the crèche which was French dominant. In this crèche, Ms. Sandy and Ms. Anna had been hired to speak Luxembourgish to familiarize children with this language. Given that the children and the French-speaking colleagues understood very little if any Luxembourgish, the two caregivers found it difficult to apply this monolingual policy. Table 1 provides some details of the professionals, their institutions, the number of children and their language backgrounds. 
Table 1. Overview of the practitioners

The following letters stand for the languages: Ar for Arabic, Al for Albanian, B for Bulgarian, SCB for Serbian/Croatian/Bosnian, Ch for Chinese, Cv for Cape Verdean Creole, $\mathrm{Cz}$ for Czech, D for Danish, En for English, Es for Estonian, Fr for French, Fi for Finish, $\mathrm{G}$ for German, $\mathrm{H}$ for Hungarian, I for Italian, $\mathrm{L}$ for Luxembourgish, $\mathrm{P}$ for Portuguese, R for Russian, Sp for Spanish and Sw Swedish.

\begin{tabular}{|c|c|c|c|c|c|}
\hline Teacher & School & $\begin{array}{l}\text { Languages } \\
\text { spoken }\end{array}$ & Qualification & $\begin{array}{l}\text { Nr of } \\
\text { chil- } \\
\text { dren }\end{array}$ & $\begin{array}{l}\text { Home languages of } \\
\text { children }\end{array}$ \\
\hline Ms. Clara & \multirow{2}{*}{$\begin{array}{l}\text { Précoce } \\
\text { (South) }\end{array}$} & L, G, Fr, En, P & teacher & \multirow[t]{2}{*}{11} & \multirow[t]{2}{*}{$\mathrm{Ar}, \mathrm{Cv}, \mathrm{Fr}, \mathrm{P}, \mathrm{SCB}$} \\
\hline Ms. Jane & & L, G, Fr, En, (P) & caregiver & & \\
\hline Ms. Vivian & $\begin{array}{c}\text { Preschool } \\
\text { (South of Center) }\end{array}$ & $\mathrm{L}, \mathrm{G}, \mathrm{Fr}, \mathrm{En}, \mathrm{Sp}$ & teacher & 18 & $\begin{array}{l}\text { Ar, Al, Ch, Cz, En, } \\
\text { Es, Fr, G, Fi, L, Sp, P }\end{array}$ \\
\hline Ms. Anna & \multirow{2}{*}{$\begin{array}{l}\text { Crèche } \\
\text { (Center) }\end{array}$} & $\mathrm{L}, \mathrm{G}, \mathrm{Fr}, \mathrm{En},(\mathrm{P})$ & caregiver & \multirow[t]{2}{*}{15} & \multirow{2}{*}{$\begin{array}{l}\text { B, En, Fr, G, H, I, L, } \\
\text { P, Sp, S }\end{array}$} \\
\hline Ms. Sandy & & L, G, Fr, En, P & caregiver & & \\
\hline Mr. Ted & \multirow{2}{*}{$\begin{array}{l}\text { day-care center } \\
\text { (North East of } \\
\text { Center) }\end{array}$} & L, G, Fr, En & caregiver & \multirow[t]{2}{*}{21} & \multirow{2}{*}{$\begin{array}{l}\text { Ar, D, En, Fi, Fr, G, } \\
\text { L, P, R, Sp, SCB }\end{array}$} \\
\hline Mr. Ken & & $\mathrm{L}, \mathrm{G}, \mathrm{Fr}, \mathrm{En}, \mathrm{Sp}$ & caregiver & & \\
\hline
\end{tabular}

\subsection{Methods}

The following sections provide insights into the qualitative and quantitative methods.

\subsubsection{Observations and interviews}

The research team observed the participants during 103 days in the four settings and videorecorded activities lasting between two and 30 minutes. For the present article, we used 146 videos recorded by the research assistant, Kirsch and the doctoral student Mortini. The observed activities included storytelling, planned activities focused on language development (e.g. memory games), rituals, art work, and singing. In order to compare the language use, we tried to choose a similar number of storytelling and language activities in each setting during a similar number of days of observations. A second set of data stems from the six video-recorded network meetings. Of particular interest were the discussions of the video-recorded activities which provided insights into the participants' perspectives on multilingualism, activities and language learning. A total of 24 clips were discussed: 6 from the éducation précoce, 3 from the preschool, 8 from the crèche, and 7 from the day-care center. In addition to the observations, Kirsch and Mortini carried out 23 semi-structured interviews with the participants about their language use, activities and practices. Table 2 
gives an overview of the data collected in each setting. Videos of activities as well as information on the project are displayed on the project's website http://mulipec.uni.lu.

Table 2. Overview of the of the quantity and type of data collected in the four research contexts

\begin{tabular}{|l|c|c|}
\hline \multicolumn{1}{|c|}{ Setting } & Number of video-recorded activities & Number of interviews \\
\hline Précoce & 40 & 5 \\
\hline Preschool & 40 & 5 \\
\hline Crèche & 38 & 7 \\
\hline Day-care center & 28 & 6 \\
\hline
\end{tabular}

\subsubsection{The questionnaire}

The questionnaire was developed by Kirsch and Seele (Ministry of Education) with the support of Curdt-Christiansen, Kratzmann, Lengyel and Panagiotopoulou, four experts from England and Germany. To compare results, some items drew on previous research studies (e.g. Kratzmann et al., 2017; MENJE \& INSIDE, 2015). The questionnaire comprised four sections. The first one included questions about biographical details of the participants (e.g. age, qualification, nationality, languages spoken at home) and professional details (e.g. length of experience, number of languages in the group, location of the institution). The second section comprised 51 items on a five-point-Likert-scale (from 'I strongly disagree' to 'I strongly agree') as well as open questions on the following topics: language learning and multilingualism in general, attitudes towards the use of Luxembourgish and home languages, attitudes towards the development of Luxembourgish and home languages, and the promotion of home languages. The third one included items on a five-point-Likert-scale (from 'never' to 'every day') as well as open questions about the type and the frequency of activities used to develop Luxembourgish, French, and home languages using books, songs, rhymes.

The final part asked about partnership with parents, documentation of language learning and professional development courses. The questionnaire, which was piloted, is described in detail in Kirsch and Aleksić (2018). Based on the research questions underlying this paper, we focus on the interest and activities in languages other than Luxembourgish.

\subsection{Data analysis}

A range of methods were used to analyze the data. 


\subsubsection{Data from observations and interviews}

All interviews and video-recordings were transcribed. Given the multimodal character of language, we included non-verbal communication strategies such as mime, gestures, actions, or intonation. Next, the observations were categorized according to the following types: storytelling activities, planned activities focused on language (e.g. retelling of stories, acting out stories, language and memory games), highly formalized and ritualized activities (e.g. telling the weather, counting children in the morning circle), singing songs, and art work. Kirsch then examined the target language and the language use during each activity. The target language refers to the language of the planned activity, for instance, a language game in Luxembourgish, a rhyme in German, a story in French. The language use refers to the actual languages deployed during the activity. For example, while reading a story in French, the professionals translanguaged using Luxembourgish and French. Kirsch calculated the percentage of activities carried out in the institutional language (Luxembourgish or French) and in a language other than this. To further examine the flexible language use, she carried out a micro-analysis of the interactions between the adults and the children thereby drawing on Seedhouse's (2005) 'sociocultural approach to conversation analysis'. Finally, together with three trained assistants, she coded for language-supporting strategies such as asking questions or elaborating (Alstad and Tkachenko, 2018). This process was both inductive and deductive, influenced by literature on language-promoting strategies. The observations of the PD and the interviews were analyzed with thematic analysis (Braun \& Clarke, 2013). The codes used in the analysis included language ideologies, beliefs, knowledge, skills (e.g. planning), language use, and translanguaging.

\subsubsection{Data from the questionnaire}

In this paper we focus on two topics of the questionnaire: interest in languages other than Luxembourgish (12 items; e.g., 'I show children that their family languages are important and valued') and activities in languages other than Luxembourgish (10 items; e.g. 'singing songs', 'telling stories'). The questionnaire was completed before and after the 15-hour training by the 44 participants, thus in May and June 2016. The seven practitioners who continued for another year, completed it a third time at the end of the PD in September 2017. Aleksić calculated the aggregated scores for both topics and then plotted them at each time point. Given that only seven participants completed the questionnaire three times, we 
present the participants' scores graphically with regards to the topics of interests and activities in languages other than Luxembourgish.

Finally, the research team triangulated the data (Flick, 2011) and discussed all findings with the external scientific advisors of our project to improve the trustworthiness of the results. The analysis of patterns across the data revealed the following themes: ideologies, well-being, planning and monitoring skills, responsible language use, understanding of language learning, education and care, professional experience and development.

\section{Findings}

The following sections, structured along the three research questions, present the participants' growing interest in activities in languages other than the institutional one and their changed attitudes towards translanguaging (1); the type of activities carried out in languages other than the institutional one (2); and the translanguaging practices (3). Each time, we will show how the PD contributed to this change.

\subsection{Growth in interest in multilingual activities and changed attitudes towards translanguaging}

While all seven professionals believed multilingualism to be an asset they were nevertheless skeptical regarding multilingual activities and translanguaging at the beginning of the PD.

\section{Changing interest in multilingual activities}

Given the long-standing monolingual policies, all practitioners apart from those in the crèche had developed a habit of focusing on Luxembourgish. In the interviews in September 2016, they explained that children may be confused if they heard several languages and may learn less Luxemburgish as a result of less input and the confusion. They also reported that parents and teachers expected children to learn Luxembourgish before they started primary school. Their interest in promoting home languages, particularly French, through activities and in daily conversations was relatively low at the beginning of the PD but their interest increased as indicated in the questionnaires. This was expected as we asked them to carry out and document two activities in languages other than the institutional one. Drawing on the questionnaire data, we calculated the aggregated scores on the topic 'interest in languages other than Luxembourgish' (Table 3) of the seven 
participants and plotted them over the three time points, May and June 2016 and September 2017 (Graph 1).

Table 3. Participants' aggregated scores in interest in languages other than Luxembourgish over three time points

\begin{tabular}{lccc}
\hline Participants & May 2016 & June 2016 & September 2017 \\
\hline Ms. Jane & 26 & 27 & 35 \\
Ms. Clara & 26 & 27 & 35 \\
Ms. Vivian & 22 & 28 & 34 \\
Ms. Sandy & 26 & 29 & 33 \\
Mr. Ken & 24 & 27 & 35 \\
Mr. Ted & 28 & 30 & 35 \\
Ms. Anna & 26 & 27 & 35 \\
\hline
\end{tabular}

Graph 1. Plotted aggregated scores in interest in languages other than Luxembourgish in May 2016 (1), June 2016 (2), and September 2017 (3)

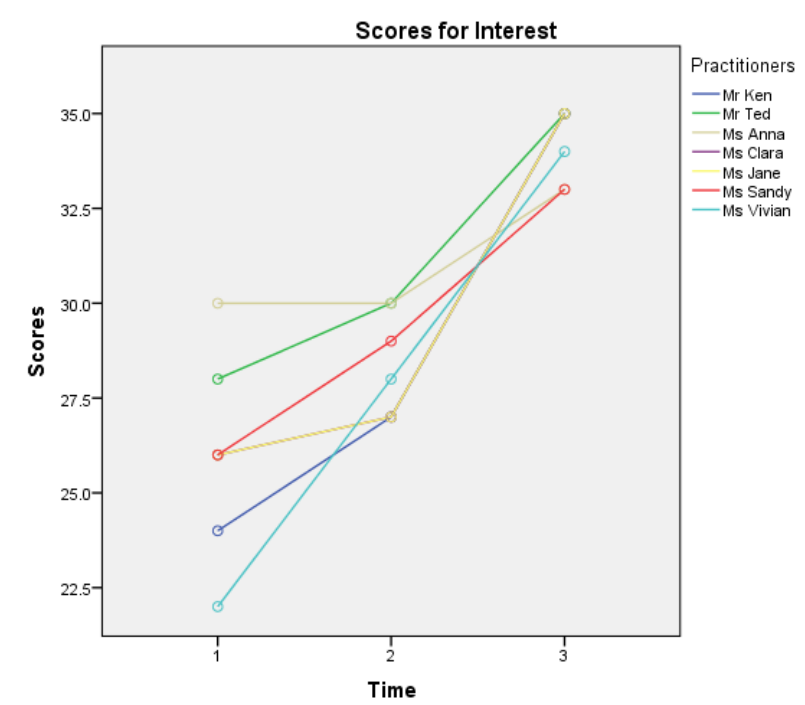

From Table 3, at Time 1, we can see that Ms. Vivian reported to be the least interested in activities other than Luxembourgish. That was expected since the language-in-educationpolicy in preschools focused on Luxembourgish. Although Mr. Ken and Mr. Ted worked in the same day-care center, their interest differed, with Mr. Ken showing the second lowest interest and Mr. Ted the highest. All other professionals reported a similar degree of interest. At Time 2, we observed a general increase of interest for all participants. The 
scores of Ms. Jane and Ms. Clara overlapped which can be explained on account of their teamwork. Finally, at Time 3, there was a general increase for all participants. Since no further analysis of these data was conducted due to the small sample, the interpretation based on the questionnaire could be tentative. However, it is supported by the findings of the qualitative data.

The interview data provide further insights into the reasons for this new interest. Firstly, upon reflection, Mr. Ken, Ms. Clara and Ms. Jane realized that home languages contributed to the children's well-being and, therefore, were important throughout the year. In September 2016, the professionals agreed on the usefulness of the home languages in the settling-in phase, but nevertheless hold that they needed to fade them out to help children learn Luxembourgish.

The children feel more accepted and understood. Furthermore, they are less anxious when you explain what you want from them in their language. They develop a feeling of safety. And step-by-step you can speak more Luxembourgish.

(Interview Ms. Clara, September 2016)

Over the course of the PD, the professionals realized the relationships between wellbeing, identity, and language use and continued to draw on home languages as shown in section 5.3. A second reason for the increased interest in home languages and languages other than the institutional one, was their reflection on language activities and their realization of the children's enjoyment and participation. Ms. Clara and Ms. Jane, for instance, focused on Luxembourgish as none of the children in their class spoke Luxembourgish at the beginning of the academic year. They felt that the children's progress was very slow despite their input in Luxembourgish and were reluctant to introduce yet another language. Following the PD requirement to implement two non-Luxembourgish activities, they sang a French song and were surprised by the children's positive reactions. The children were highly motivated, sang on their own and asked to sing the new song in class. Finally, the practitioners realized that giving children spaces to use their home languages during free-play may lead neither to an inclusive environment nor to automatic language learning. While watching videos of children interacting during free-play in our PD, they noted that instances of peer-learning were rare in some settings and that some three-year-olds deliberately used their home language to exclude peers. The practitioners came to understand the need to plan specific activities to include all children and value all languages. In sum, the PD led to a change in the interest in activities in non-institutional 
languages by encouraging activities and promoting reflection on their language use in daily interactions and during activities.

\section{Changed understanding of translanguaging}

According to the interview data, the teachers and the practitioners in the day-care center were unfamiliar with translanguaging before the PD. They believed that it was important to speak Luxembourgish to provide maximum input and valued language separation. Rare switches to the child's home language occurred mainly at the beginning of the year to ensure comprehension. By contrast, multilingualism was part of the daily practice of Ms. Anna and Ms. Sandy. In the excerpt below, Ms. Sandy explained that, though she had been hired to speak Luxembourgish, she frequently switched to different languages to accommodate the children's interests and needs.

Well, I have the advantage that I have more languages and I try to jump from one language to another so that kids feel good and where I say to myself I can allow myself [to communicate] in Luxembourgish or German. When the German child says, I would like to sing that song, then we sing that song. Or we had the little Portuguese child who said I would like to sing that song in Portuguese and then we sang it in Portuguese. (...) It is what I daily do with the children, I really jump from one language to the other, spontaneously, without saying, well, I have to pay attention. I ensure that Luxembourgish always remains there, that is my main [task]. When I see that children don't follow, then I get back either in French or with a language I can express myself in. And then I add Luxembourgish once again. (Interview, September 2016)

Although Ms. Anna and Ms. Sandy translanguaged daily, they felt 'guilty' when doing so (interviews May, July and September 2017). The theoretical input on language learning in the PD and the discussions helped all practitioners understand that strict language separation was not necessary for language learning and that there was no need for a practice of linguistic interdiction. By the end of the $\mathrm{PD}$, all practitioners had opened up to translanguaging and reported drawing on children's home languages. Mr. Ken explained that he felt good, 'almost freed' up because he let children communicate in a language of their choice without him 'having to ask 'do I have to intervene, do I have to insist on Luxembourgish?'. He believed that he could better accommodate the children's needs. The other participants similarly reported using home languages more frequently and feeling 'relieved' and 'less enclosed' (March and June 2017). In sum, the PD enabled the practitioners to deepen their knowledge of language learning and encouraged reflection on 
language use, which, in turn, contributed to opening up to home languages and multilingual activities.

\subsection{Increase of activities in non-institutional languages}

The interviews and the observations showed that the practitioners had a very different starting point in relation to planning activities. The professionals in the formal settings were used to planning but had to learn to embed non-Luxembourgish activities in a meaningful context. The practitioners in the crèche were used to designing a meaningful translingual child-centered environment but had to learn to plan activities. The professionals in the daycare center also had to learn to plan activities but moreover, they needed to change their perception of their role as caregivers to that as educators.

\section{Type of language promoting activities}

Table 4 provides an overview of the type of video-recorded activities in the four settings. Given the focus on storytelling and activities around stories in the PD, it is not surprising that these activities were dominant. Singing songs in many languages and engaging in ritualized activities such as talking about the daily schedule and reciting a rhyme before dinner, occurred daily in the formal educational settings and the crèche but more rarely in the day-care center. Topic-based art work where key vocabulary was revisited happened in all settings but less frequently in the day-care centre. Activities were mainly in French, those in home languages were rare.

Table 4. Overview of the type of activities

\begin{tabular}{|l|c|c|c|c|c|c|}
\hline $\begin{array}{c}\text { Percentage of } \\
\text { activities per setting }\end{array}$ & $\begin{array}{c}\text { story- } \\
\text { telling }\end{array}$ & $\begin{array}{c}\text { focused } \\
\text { language } \\
\text { activities }\end{array}$ & $\begin{array}{c}\text { ritualized } \\
\text { activities }\end{array}$ & singing & art work & N \\
\hline Précoce & $18 \%$ & $25 \%$ & $25 \%$ & $15 \%$ & $18 \%$ & 40 \\
\hline Preschool & $18 \%$ & $28 \%$ & $25 \%$ & $15 \%$ & $15 \%$ & 40 \\
\hline Crèche & $16 \%$ & $27 \%$ & $16 \%$ & $27 \%$ & $16 \%$ & 38 \\
\hline Day-care center & $25 \%$ & $36 \%$ & $15 \%$ & $14 \%$ & $11 \%$ & 28 \\
\hline
\end{tabular}

The interviews indicated that the PD helped the professionals plan and carry out interactive activities around storytelling, rhymes and songs. Ms. Clara reported that she gained many new ideas from watching the video-recorded activities of her colleagues. Ms. Sandy, Ms. Vivian and M. Ken appreciated the constructive feedback they received either 
during the discussion of their video-recorded activities or during the coaching (interviews September 2017).

Planned language use in the video-recorded activities

The video-recordings showed that the practitioners in the day-care center narrated several stories in French and two rhymes, in German towards the end of the PD. Expressed in percentages, $43 \%$ of their storytelling activities was not carried out in the institutional language Luxembourgish. Table 5 presents the percentage of activities planned in languages other than the institutional one. The percentage of the day-care practitioners' rituals and songs in languages other than Luxembourgish seems relatively high $(50 \%$ and $75 \%$ in Table 5) but the overall percentage of rituals and songs was low (see Table 4). The situation differed in the crèche where Ms. Sandy and Ms. Anna told stories mainly in Luxembourgish and French. Only two of their storytelling activities (66\%) were entirely in French and only one was in German, planned with the aim of valuing the home language of one boy. All other activities were translingual because Ms. Sandy and Ms. Anna switched between French, Luxembourgish and at times Portuguese and German (see also 5.3). By contrast, in the formal sector, the percentage of non-Luxembourgish activities was low and the increase was related to the PD. On account of the monolingual language-in-educationpolicy and the intake in the éducation précoce, the professionals focused initially on Luxembourgish and only offered activities in other languages in the second half of the academic year. In Ms. Vivian's words:

I did not have a multilingual practice until the moment I did this professional development. Without it, I would never have done rhymes in German and French with the children and I would probably never have read a book in a language other than Luxembourgish to them. (Interview, September 2016)

Table 5. Percentage of activities planned in non-institutional languages across the settings

\begin{tabular}{|c|c|c|c|c|c|c|}
\hline 'Other' & storytelling & $\begin{array}{c}\text { focused } \\
\text { language } \\
\text { activities }\end{array}$ & rituals & singing & art work & N \\
\hline Précoce & $29 \%$ & $10 \%$ & $20 \%$ & $16 \%$ & $0 \%$ & 40 \\
\hline Preschool & $14 \%$ & $27 \%$ & $10 \%$ & $50 \%$ & $0 \%$ & 40 \\
\hline Crèche & $66 \%$ & $100 \%$ & $100 \%$ & $100 \%$ & $100 \%$ & 38 \\
\hline Day-care & $43 \%$ & $40 \%$ & $50 \%$ & $75 \%$ & $0 \%$ & 28 \\
\hline
\end{tabular}




\section{Development of language activities over time}

While the interviews and observations between September 2016 and September 2017 provide insights into the type of activities and the languages used, the questionnaire data reveal the perceived increase in activities over time. As with the previous topic, we calculated the aggregated scores on the topic 'activities in languages other than Luxembourgish' (Table 6) of the seven participants and plotted them over the three time points, May and June 2016 and September 2017. Graph 2 visualizes the development of activities in languages other than the institutional one over the three time points. The increase in activities from the first to the second and especially from the second to the third measurement parallels the increase in the interest in other languages shown in Table 3 and Graph 1.

Table 6 and Graph 2 indicate that at Time 1, Ms. Clara, Ms. Jane, and Ms. Vivian reported carrying out the least non-Luxembourgish activities. Ms. Anna and Ms. Sandy differed in their perceptive of the frequency of activities carried in a non-institutional language. Ms. Sandy's score is understandable if she thought of the multilingual songs daily performed in the crèche at the time of completing the questionnaire. The high scores of Mr. Ted and Mr. Ken which indicate frequent activities is in contrast to our latter observations. At Time 2, there was a general increase for all participants but especially for Mr. Ted and Mr. Ken, for whom planning was a novel activity. These higher scores reflect the actual increase in their activities which were discussed during the PD, but they do not accurately represent their practice. Finally, at Time 3, there was an increase for six participants. Mr. Ted reported a slight decrease, possibly related to the fact that he spent less time in his group because he took on more administrative work.

Table 6. Participants' aggregated scores in activities in languages other than Luxembourgish over three time points (from the five-point-Likert-scale questionnaire)

\begin{tabular}{lccc}
\hline Participants & May 2016 & June 2016 & September 2017 \\
\hline Ms. Jane & 22 & 24 & 30 \\
Ms. Clara & 22 & 23 & 30 \\
Ms. Vivian & 23 & 29 & 36 \\
Ms. Sandy & 29 & 31 & 32 \\
Mr. Ken & 32 & 40 & 43 \\
Mr. Ted & 31 & 40 & 38 \\
Ms. Anna & 23 & 25 & 35 \\
\hline
\end{tabular}


Graph 2. Participants' aggregated scores in activities in languages other than Luxembourgish in May 2016 (1), June 2016 (2), and September 2017 (3)

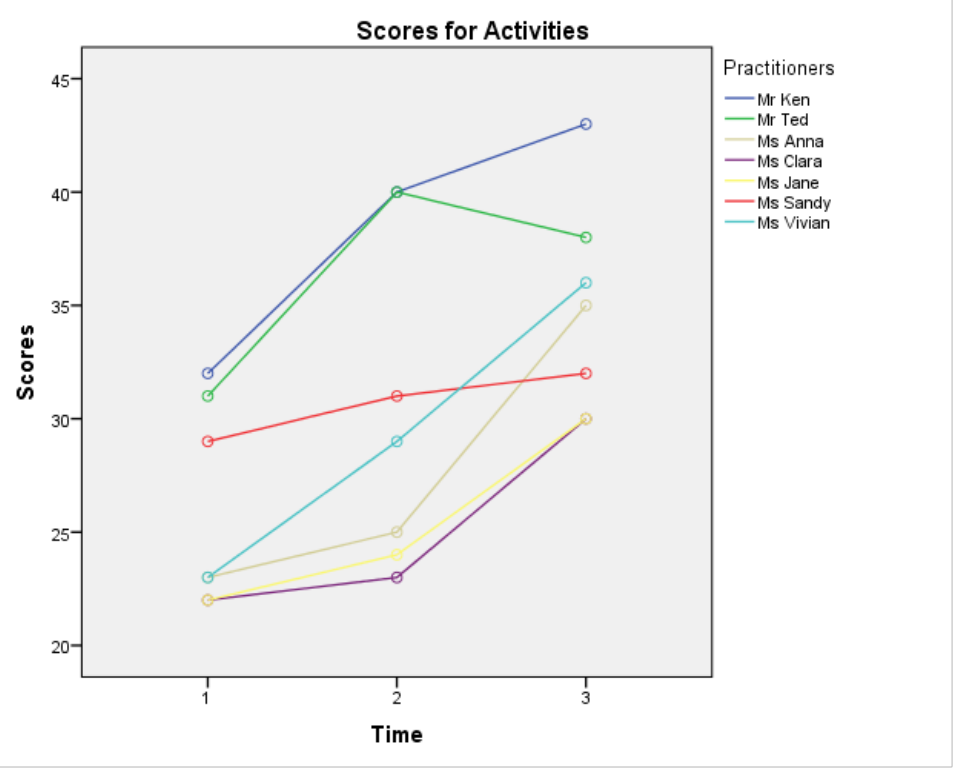

To progress from carrying out isolated activities to embedding them in a holistic learning environment is a sign of changing one's pedagogical practice. This change was apparent from February 2017 in the video-recorded activities of Ms. Clara and Ms. Jane, Ms. Vivian as well as Ms. Anna and Ms. Sandy. The professionals managed to design a holistic childcentered language learning environment where children encountered multiple languages both in guided activities such as dialogic reading, memory games, songs and rhymes, and in daily interactions. This meaningful learning environment was rooted in children's needs and provided them with repeated opportunities to hear and use the same language structures in a range of authentic situations. For instance, in May 2017, Ms. Clara and Ms. Jane organized multilingual activities around caterpillars. They had caterpillars in the classroom for children to observe, told stories in Luxembourgish and French, sang a Portuguese song and created Luxembourgish games. While Mr. Ken and Mr. Ted organized some activities around books and rhymes, they found it difficult to embed language learning in quality interactions throughout the day. All professionals agreed that their new planning skills were the result of their reflection on their practice and the feedback they received through the PD and during coaching.

In sum, the findings have shown that the seven practitioners learned to plan and implement a range of activities (mainly) in French and German over the PD. This change of practice has to be seen in relation to their changed attitudes to languages and translanguaging presented in 5.1. 


\subsection{Translanguaging in language activities}

Given the language diversity of the children, all professionals needed to scaffold the children's language learning independently of the target language. Translanguaging was a key strategy to ensure communication and comprehension. Table 7 provides an overview of the percentage of all video-recorded activities where the professionals translanguaged, thus, used their entire semiotic repertoire for communication. The table lists the same activities as Table 4 apart from singing. The percentage of flexible language use depends both on the setting and the activities. Translanguaging was a daily practice in the crèche, occurred in the day-care center and was frequent in the formal settings.

Table 7. Percentage of activities where the professionals translanguaged

\begin{tabular}{|c|c|c|c|c|c|c|}
\hline TL & storytelling & $\begin{array}{c}\text { focused } \\
\text { language } \\
\text { activities }\end{array}$ & rituals & art work & total & N \\
\hline Précoce & $71 \%$ & $50 \%$ & $40 \%$ & $86 \%$ & $59 \%$ & 34 \\
\hline Preschool & $57 \%$ & $64 \%$ & $70 \%$ & $67 \%$ & $65 \%$ & 34 \\
\hline Crèche & $66 \%$ & $100 \%$ & $100 \%$ & $100 \%$ & $89 \%$ & 28 \\
\hline Day-care & $43 \%$ & $70 \%$ & $50 \%$ & $0 \%$ & $50 \%$ & 24 \\
\hline
\end{tabular}

The data from the 146 video-recordings also indicate that translanguaging was used differently across settings. The professionals in the day-care center and the preschool translanguaged mainly to address the individual needs of the children. Mr. Ken and Mr. Tom were frequently observed switching from Luxembourgish to the children's home languages even if the children showed no signs of misunderstanding. This was the case in November 2016, when Mr. Ken and an English-speaking child communicated in Luxembourgish and Mr. Ken suddenly asked a question in English which the child answered in Luxembourgish. Mr. Ken and Mr. Tom explained that translanguaging helped them address the children's language backgrounds but they often failed to assess their needs and whether a language change was required.

By contrast, Ms. Vivian carefully monitored her own and the children's language use. She switched to French and Spanish during circle time or art work delivered in Luxembourgish to help French-speaking or Spanish-speaking children if she perceived this switch to be helpful. She also opened translanguaging spaces where she allowed children to speak Spanish or French while she used Luxembourgish. In whole class language activities, she used the target language using mime, gestures and pictures. She accepted the children's 
answers in Luxembourgish and translated them into French.

The professionals in the crèche and the éducation précoce translanguaged both when addressing the whole group and with individual children. During dialogic reading, they interconnected verbal strategies such as asking questions, elaborating, rephrasing and giving corrective feedback as well as non-verbal strategies such as mime, gesture and voice modulation to ensure comprehension and participation. They also translated when necessary from the institutional languages to home languages and vice versa. The following representative observation illustrates the flexible language use of Ms. Anne and Ms. Sandy: In December 2016, they had told the children a story about cats and mice and spoke about it the following day. One child pointed to a woolen ball in the picture, calling it a cat. Ms. Anna asked in Luxembourgish if this was really a cat. When none of the children answered, Ms. Sandy asked in French what the picture represented. In French, one girl confirmed that it was a cat. Ms. Sandy gave corrective feedback in Luxembourgish and pointed to a real cat to ensure comprehension. Some of the children promptly made the sound meow. Ms. Sandy then asked children to find a picture showing mice. A Spanish-German-speaking boy uttered the word mouse in French. Ms. Anna asked if it was one mouse, pointing to the amount of mice. He explained in German that there were several. She took up his answer and asked a clarification question in German.

The effective use of translanguaging, the need to monitor language use and the purposes of translanguaging were discussed in several networking meetings. This enabled the practitioners to become more aware of their own and the children's language use and reflect on their purpose of translanguaging. Like the other practitioners, Ms. Annick and Ms. Sandy explained that the flexible language use enabled them to attract and secure attention, ensure comprehension and value home languages. Furthermore, it enabled children to express themselves and promoted their well-being (interviews February, May, July, September 2017).

\section{Discussion}

This article set out to examine if professionals changed attitudes towards multilingual activities and translanguaging, if and how they implemented activities in multiple languages and to what extent they used languages flexibly on account of the PD. Drawing on observations, interviews, and questionnaires, the findings show that all seven practitioners opened up towards multilingual education and translanguaging, increased activities in a 
range of languages, and translanguaged frequently. We will discuss these findings as well as the influence of our PD in turn.

Our findings of the positive attitudes towards multilingualism resemble those of other early childhood practitioners (Kratzmann et al., 2017) or prospective preschool teachers (Portolés \& Martí, 2018). In contrast to other researchers, we found a positive correlation between interest in activities in non-institutional languages and activities in these languages (Kratzmann et al., 2017). The increase of activities in non-institutional languages of our practitioners is related to their understanding of the unnecessity of a strict language separation for learning (García, 2017) and the influence of home languages on language learning, well-being and identity building (Cummins, 2009). Furthermore, it was based on the practitioners' improved planning skills and their deployment of language supporting strategies, which made the activities in new languages accessible and comprehensible. Our findings are supported by interaction studies reporting on practitioners' increased use of language-supporting strategies through a PD (Hamre et al., 2012; Sachse et al., 2016). They also replicate those of Jopling et al. (2013) and Hayes et al. (2013) showing that PD can help professionals change their activities and pedagogy. Like the practitioners in the abovementioned studies, ours planned more language and literacy activities around storytelling and found a balance between guided activities and more informal interactions in the target languages. However, despite the increase in activities in mainly French and German, the practitioners had a clear preference for the majority language like professionals elsewhere (Kratzmann et al., 2017; MENJE \& INSIDE, 2015; Neumann, 2015).

The type of activities designed by our practitioners are based on social-constructivist theories of (second) language learning that hold that children learn best through social interaction and mediated activity (Vygotsky, 1978), thus, when interacting with more knowledgeable others in playful, action-oriented and contextualized activities such as shared reading, storytelling, rhymes, and songs. The latter are typical of ECEC settings in the U.S and Europe (Hayes et al., 2013; Hindman \& Wasik, 2008; MENJE \& INSIDE, 2015). While all seven practitioners learned to plan and carry out such activities, there were differences in the approaches of the professionals based on their experience of planning and teaching. The teachers and some care-givers, who carefully scaffolded the children's learning, created a child-centered and holistic learning environment that resembled those in bilingual settings (Gort and Pontier, 2013) and classes where English was taught as a foreign language to young learners (Alstad and Tkachenko, 2018; Andúgar and CortinaPeréz, 2018). 
Translanguaging became a legitimate practice in three settings. All practitioners except those in the day-care center had begun to implement a translanguaging pedagogy (García et al. 2017). Thus, they understood that translanguaging was more than a strategy.

Nevertheless, unlike the preschool teacher in Young and Mary (2016), they did not realize that translanguaging could also challenge hegemonic practices. Like the majority of the papers reviewed by Poza (2017), these five professionals in Luxembourg appeared to think of translanguaging as a resource-based pedagogy that challenges traditional conceptions of bilingualism and language learning. All seven practitioners related translanguaging to the following purposes: communication, comprehension, well-being, valuing and giving status to minority languages. These functions are in line with previous studies (García et al., 2011; Garrity et al., 2015; Gort and Pontier, 2013; Gort and Sembiante, 2015; Kirsch, 2017; Palviainen et al., 2016; Velasco and Fialais, 2018).

The final section of this paper turns to our PD and conceptualizes the practitioners' learning. As seen above, the teachers and caregivers in Luxembourg were successful in developing their understanding of language learning and their skills in planning activities and using language-supporting strategies. This, in turn, affected their practices. These findings are in line with several meta-studies in the U.S. and Europe that report on the effect of PD on outcomes and practice (Egert et al., 2018; Peleman et al., 2018; Peeters et al., 2014). The positive results may be related to the professionals' motivation to prepare themselves for the multilingual education which was about to become law, but it may also be rooted in the design of the PD. As was the case in other effective programs, ours used an 'integrated approach' (Peeters et al., 2014) and was long-term, collaborative, and based on inquiry, performance, and reflection (Egert et al., 2018; Peleman et al., 2018). The coaching and the theory-led discussions during the PD about the video-recorded activities promoted reflection. The professionals analyzed their beliefs and practices, connected theory and practice, constructed new knowledge, developed positive attitudes and began to change their practice. According to Trodd and Dickerson (2018), the ability to critically reflect on one's practice, to consider other perspectives and rethink one's own are starting points for transformation and the sustainability of change.

We conceptualize the professional learning through input, experience, and observation as visualized in Figure 2. The course, the meetings and the coaching all contributed to the development of knowledge, skills and new practices, akin to sequential models of PD (Fukkink and Lont, 2007). In addition, our request to implement activities directly influenced the multilingual practice. The practitioners remarked the children's well-being 
and motivation as well as their own relief regarding language choice and the success of the activities. The experience of these activities and their reflection fueled positive attitudes, propelled changes in their pedagogical practice and encouraged more knowledge development. In this sense, our findings are reminiscent of the studies by Palviainen et al. (2016) and Levin and Wadmany (2006) who showed that actual experiences and practices can lead to a change of knowledge and beliefs. Finally, the discussions around the videorecorded activities played an important role as they provided the professionals with insights into the practice of others, helped them identify effective strategies (Buschmann and Sachse, 2018) and adapt these to use them in their own practice. This professional learning is both reminiscent of Bandura's social learning theory and Vygotsky's social-constructivist one. Thus, our model shows that the process of learning is dynamic, complex and multilayered.

Figure 2. Learning and changing in our professional development

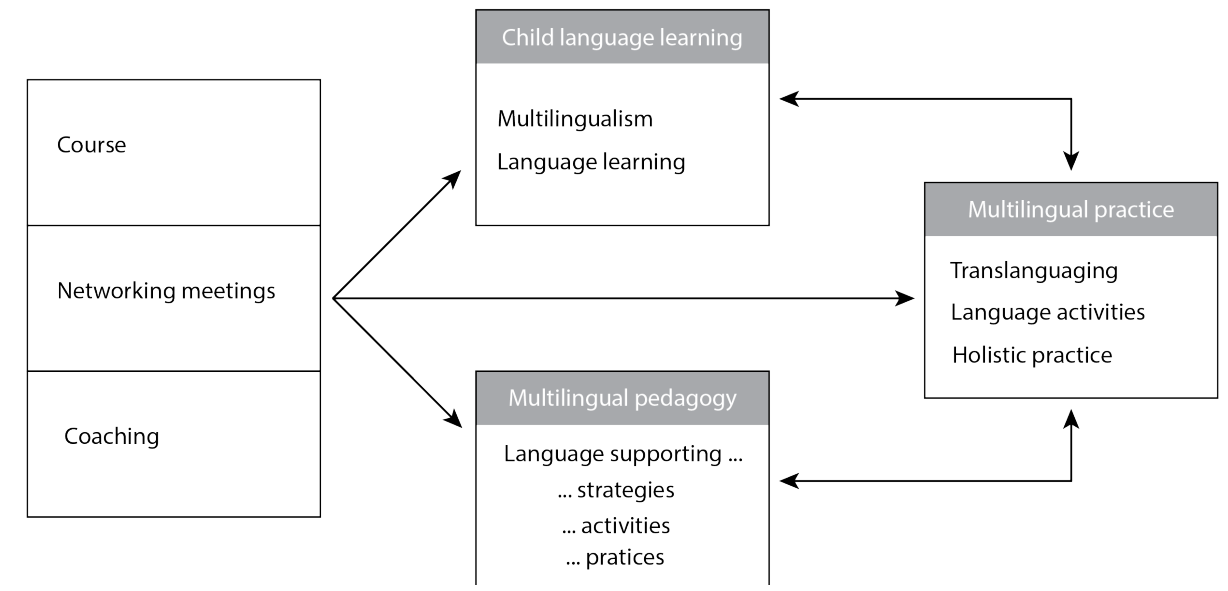

One limitation of this study is the very small number of participants, related to the longitudinal and qualitative nature of this study. Another one may be the motivation of the professionals. They were aware of the upcoming law and interested in developing their pedagogy. Their interest may bias the findings. However, while all professionals developed their attitudes and knowledge, only five of the seven changed their practice. 


\section{Conclusion}

While this study has limitations on account of the small number of participants, it has nevertheless made several contributions. In relation to the effects of our PD, the study is important both nationally and internationally. It is the first one that has investigated the attitudes and practices of professionals prior to the change of law in early childhood education as well as the effect of professional development in Luxembourg. Based on follow-up meetings with the practitioners in 2018, the experience of Kirsch co-teaching with Ms Anna in PD courses from 2018, and a follow-up case-study of Ms Vivian (Breser, 2019), there are indications that our PD was sustainable, an important criterion for the success of PD.

We conclude with two implications. Our findings showed that the practitioners opened up to translanguaging for learning and began to use languages flexibly. There is a need for further trainings to help practitioners understand that translanguaging is a resource-oriented pedagogy rather than a mere strategy and that this pedagogy can fight social inequalities. In addition, the findings showed that the professional learning depended on the practitioners' experiences which varied with the local context. Our coaching was therefore essential. We conclude that the positive effects of a PD could be increased with more coaching and with the involvement of the management team which, when trained, can support their staff (Buschmann \& Sachse, 2018; Peeters et al., 2014). Internationally, the study fills an important research gap. Currently, there have been very few studies on PD on multilingualism in early childhood and ours shows that integrated programs can be effective if they are collaborative, long-term and performance and inquiry-based, and include coaching (Egert at al. 2018; Peleman et al., 2018). Finally, in contrast to existing sequential models (Fukkink and Lont, 2007), our paper helped to conceptualize professional learning by presenting a dynamic model of change.

\section{Funding details}

This work was supported by the National Research under Grant C15/SC/9989225 and The Ministry of Education, Childhood and Youth under the name MuLiPEC.

\section{References}

Alamillo, L., Yun C., \& Bennett, L. H. (2017). Translanguaging in a Reggio-inspired Spanish duallanguage immersion programme. Early Child Development and Care, 187(3-4), 469-486. doi: 
$10.1080 / 03004430.2016 .1236091$

Alstad, G. T., \& Tkachenko, E. (2018). Teachers' Beliefs and Practices in Creating Multilingual Spaces: The Case of English Teaching in Norwegian Early Childhood Education. In M. Schwartz (Ed.), Preschool Bilingual Education. Agency in Interactions between Children, Teachers, and Parents (pp. 245-282). Dordrecht, Netherlands: Springer.

Andúgar, A., \& Cortina-Peréz, B. (2018). EFL Teachers' Reflections on Their Teaching Practice in Spanish Preschools: A Focus on Motivation. In M. Schwartz (Ed.), Preschool Bilingual Education: Agency in Interactions between Children, Teachers, and Parents (pp. 218-245). Dordrecht, Netherlands: Springer.

Bandura, A. (1986). Social foundations of thought and action: A social cognitive theory. Englewood Cliffs, NJ: Prentice Hall.

Bialystok, E. (2017). The bilingual adaptation: How minds accommodate experience. Psychological Bulletin, 143(3), 233-262. doi.org/10.1037/bul0000099

Braun, V., \& Clarke. V. (2006). Using thematic analysis in psychology. Qualitative Research in Psychology, 3, 77-101. doi: 10.1191/1478088706qp063oa

Breser, N. (2019). Translanguaging: eine Fallstudie in der Luxemburgischen Vorschule. [Translanguaging: a case-study of a Luxembourgish preschool]. Unpublished MA study. Esch: University of Luxembourg.

Buschmann, A., \& Sachse, S. (2018). Heidelberg interaction training for language promotion in early childhood settings (HIT). European Journal of Education, 53(1), 66-78. doi: 10.1111/ejed.12263

Chapman De Sousa, E.B. (2017). Promoting the contributions of multilingual preschoolers. Linguistics and Education, 39, 1-13. doi: 10.1016/j.linged.2017.04.001

Council of the European Union. (2011). Council conclusions on early childhood education and care: Providing all our children with the best start for the world of tomorrow. (2011/C 175/03). Retrieved from https://publications.europa.eu/en/publication-detail//publication/f9674565-5714-4453-8dd1-72126e63b423/language-en

Cummins, J. (2009). Pedagogies of choice: challenging coercive relations of power in classrooms and communities. International Journal of Bilingual Education and Bilingualism, 12(3), 261271. doi: $10.1080 / 13670050903003751$

Egert, F., Fukkink, R. G., \& Eckhardt, A. G. (2018). Impact of In-Service Professional Development Programs for Early Childhood Teachers on Quality Ratings and Child Outcomes: A MetaAnalysis. Review of Educational Research June, 88(3), 401-433. doi: $10.3102 / 0034654317751918$

Flick, U. (2011). Triangulation. Eine Einführung [Triangulation. An introduction]. Wiesbaden, Germany: VS Verlag.

Fukkink, R. G., \& Lont, A. (2007). Does training matter? A meta-analysis and review of caregiver training studies. Early Childhood Research Quarterly, 22(3), 294-311. doi: 10.1016/j.ecresq.2007.04.005

García, O. (2017). Translanguaging in schools: Subiendo y Bajando, Bajando y Subiendo as Afterword. Journal of Language, Identity \& Education, 16(4), 256-263. doi: 10.1080/15348458.2017.1329657

García, O., Makar, C., Starcevic, M., \& Terry, A. (2011). Translanguaging of Latino kindergarteners. In K. Potowski \& J. Rothman (Eds.), Bilingual youth: Spanish in Englishspeaking societies (pp. 33-55). Amsterdam, Netherlands: John Benjamins.

García, O., \& Flores, N. (2011). Multilingual pedagogies. In: M. Martin-Jones, A. Blackledge \& A. Creese (Eds.), The Routledge Handbook on Multilingualism (pp. 232-242). London, England: Routledge.

García, O., \& Li Wei (2014). Translanguaging: Language, Bilingualism and Education. New York, NY: Palgrave Macmillan.

García, O., Johnson, S. I., \& Seltzer, K. (2017). The Translanguaging Classroom: Leveraging Student Bilingualism for Learning. Philadelphia, PA: Caslon.

Garrity, S., Aquino-Sterling, C. R., \& Day, A. (2015). Translanguaging in an Infant Classroom: Using Multiple Languages to Make Meaning. International Multilingual Research Journal, 9, 177-196. doi: 10.1080/19313152.2015.1048542 
Gort, M., \& Pontier, R. W. (2013). Exploring bilingual pedagogies in dual language preschool classrooms. Language and Education, 27(3), 223-245. doi: 10.1080/09500782.2012.697468

Gort, M., \& Sembiante, S. F. (2015). Navigating Hybridized Language Learning Spaces Through Translanguaging Pedagogy: Dual Language Preschool Teachers' Languaging Practices in Support of Emergent Bilingual Children's Performance of Academic Discourse. International Multilingual Research Journal, 9, 7-25. doi: 10.1080/19313152.2014.981775

Hamre, B. K., Pianta, R. C., Burchinal, M., Field, S., LoCasale-Crouch, J., Downer, J. T., Howes, C., LaParo, K., \& Scott-Little, C. (2012). A Course on Effective Teacher-Child Interactions: Effects on Teacher Beliefs, Knowledge, and Observed Practice. American Educational Research Journal, 49(1), 88-123. doi: 10.3102/0002831211434596

Hayes, N., Siraj-Blatchford, I., Keegan, S., \& Goulding, E. (2013). Evaluation of the Early Years Programme of the Childhood Development Initiative. Retrieved from Childhood Development Initiative website: https://www.cdi.ie/wp-content/uploads/2016/11/CDI-

Early_Years_Report_24.01-web-1.pdf

Hindman, A. H., \& Wasik, B. A. (2008). Head Start teachers' beliefs about language and literacy instruction. Early Childhood Research Quarterly, 23(4), 479-492. doi: 10.1016/j.ecresq.2008.06.002

Jopling, M., Whitmarsh, J., \& Hadfield, M. (2013). The challenges of evaluation: assessing Early Talk's impact on speech language and communication practice in children's centres. International Journal of Early Years Education, 21(1), 70-84. doi: 10.1080/09669760.2013.771324

Kirsch, C. (2017). Young children capitalising on their entire language repertoire for language learning at school. Language, Culture and Curriculum, 31(1), 39-55. doi: 10.1080/07908318.2017.1304954

Kirsch, C., \& Aleksić, G. (2018). The Effect of Professional Development on Multilingual Education in Early Childhood in Luxembourg. Review of European Studies, 10(4), 1-18. doi: 10.5539/res.v10n4p148

Kratzmann, J., Jahreiß, S., Frank, M., Ertanir, B., \& Sachse, S. (2017). Einstellungen pädagogischer Fachkräfte in Kindertageseinrichtungen zur Mehrsprachigkeit [Beliefs on multilingualism of practitioners in early years institutions]. Zeitschrift für Erziehungswissenschaft, 20(2), 237258. doi: 10.1007/s11618-017-0741-7

Levin, T., \& Wadmany, R. (2006). Teachers' Beliefs and Practices in Technology-based Classrooms: A Developmental View. Journal of Research on Technology in Education, 39(2), 157-181. doi: 10.1080/15391523.2006.10782478

Lewis, G., Jones, B., \& Baker, C. (2012). Translanguaging: developing its conceptualisation and contextualisation. Educational Research and Evaluation: An International Journal on Theory and Practice, 18(7), 655-670. doi: 10.1080/13803611.2012.718490

Li Wei (2018). Translanguaging as a Practical Theory of Language. Applied Linguistics, 39(1), 930. doi: 10.1093/applin/amx039

Ministry of National Education, Childhood and Youth of Luxembourg and Integrative Research Unit on Social and Individual Development of the University of Luxembourg. (2015). D'Éducation précoce: Mat de Kanner, fir d'Kanner! Bericht [Preschool education: with children, for children! Report]. Retrieved from http://www.men.public.lu/cataloguepublications/fondamental/statistiques-analyses/autres-themes/education-precoce/ed-prec.pdf

Ministry of National Education, Childhood and Youth of Luxembourg and National Youth Service. [MENJE] (2018). Cadre de référence national sur l'éducation non formelle des enfants et des jeunes. [National curriculum framework for non-formal education for children and Youth]. Luxembourg: MENJE \& SNJ.

Ministry of National Education, Childhood and Youth of Luxembourg. [MENJE] (2018a). Information about the PISA Study 2018. Retrieved from http://www.men.public.lu/cataloguepublications/secondaire/etudes-internationales/pisa-2018/brochure-en.pdf

Ministry of National Education, Childhood and Youth of Luxembourg. [MENJE] (2019).

Statistiques globales et analyses des résultats scolaires. [Global statistics and analysis of school results.] Retrieved from http://www.men.public.lu/fr/actualites/publications/

fondamental/statistiques-analyses/statistiques-globales/index.html 
National Institute for Statistics and Economic Studies of Luxembourg. [MENJE] (2019). Luxembourg in figures 2019. Luxembourg, Luxembourg: STATEC.

Neumann, S. (2015). Lost in Translanguaging? Practices of Language Promotion in Luxembourgish Early Childhood Education. Global Education review, 2(1), 23-39.

Otheguy, R., García, O. \& Reid, W. (2015). Clarifying translanguaging and deconstructing named languages: a perspective from linguistics. Applied Linguistics Review, 6(3), 281-307.

Palviainen, A.., Protassova, E., Mård-Miettinen, K., \& Schwartz, M. (2016). Two languages in the air: A cross-cultural comparison of preschool teachers' reflections on their flexible bilingual practices. International Journal of Bilingual Education and Bilingualism, 19(6), 614-630. doi: 10.1080/13670050.2016.1184615

Peleman, B., Lazzari, A., Budginaite, I., Siarova, H., Hauari, H., Peeters, J., \& Cameron, C. (2018). Continuous professional development and ECEC quality: Findings from a european systematic literature review. European Journal of Education, 53(1), 9-22. doi: 10.1111/ejed.12257

Peeters, J., Cameron, C., Lazzari, A., Peleman, B., Budginaite, I., Hauari, H., \& Siarova, H. (2014). Impact of continuous professional development and working conditions of early childhood education and care practitioners on quality, staff-child interactions and children's outcomes: A systematic synthesis of research evidence. Gent, Belgium: VBJK.

Portolés, L., \& Martí, O. (2018). Teachers' beliefs about multilingual pedagogies and the role of initial training. International Journal of Multilingualism. doi: 10.1080/14790718.2018.1515206

Poza, L. (2017). Translanguaging: Definitions, Implications, and Further Needs in Burgeoning Inquiry. Berkeley Review of Education, 6(2), 101-128. doi: 10.5070/B86110060

Sachse, S., Budde-Spengler, N., \& Schuler, S. (2016). Alltagsintegrierte Sprachförderung in Kindertagesstätten. Praktische Implikationen aus dem Projekt MAUS [Integrated language development in early years settings. Practical implications of the project MAUS]. Retrieved from the University of Education of Heidelberg:_https://www.ph-heidelberg.de/fileadmin/wp/wp sachse/Forschungsprojekte/MAUS/MAUS Broschuere.pdf

Seedhouse, P. (2005). Conversation Analysis and language learning. Language Teaching, 38(4), 165-187. doi: 10.1017/S0261444805003010

Star, J. R., \& Strickland, S. K. (2008). Learning to observe: Using video to improve preservice mathematics teachers' ability to notice. Journal of Mathematics Teacher Education 11(2), 107125. doi: 10.1007/s10857-007-9063-7

Trodd, L., \& Dickerson, C. (2018). 'I enjoy learning': developing early years practitioners' identities as professionals and as professional learners. Professional Development in Education. doi: 10.1080/19415257.2018.1459788

Velasco, P., \& Fialais, V. (2018). Moments of metalinguistic awareness in a Kindergarten class: translanguaging for simultaneous biliterate development. International Journal of Bilingual Education and Bilingualism, 21(6), 760-774. doi: 10.1080/13670050.2016.1214104

Vygotsky, L. S. (1978). Mind in Society. Cambridge: Harvard University Press.

Williams, C. (1994). Arfarniad o ddulliau dysgu ac addysgu yng nghyd-destun addysg uwchradd ddwyieithog [An evaluation of teaching and learning methods in the context of bilingual secondary education] (Doctoral dissertation). Retrieved from Prifysgol Bangor University.

Young. A., \& Mary, L. (2016). Autoriser l'emploi des langues des enfants pour faciliter l'entrée dans la langue de socialisation: Vers un accueil inclusif et des apprentissages porteurs de sens [Allow the use of the children's languages to facilitate the entry in the language of scolarisation: Towards an inclusive welcome and meaningful learning]. La nouvelle revue de l'adaptation et de la scolarisation, 73, 75-94. doi: 10.3917/nras.073.0075 